\title{
"MOSQUE ARCHITECTURE" OR ARCHITECTURE OF MOSQUE: A NEW NOTIONS OF BENGAL DURING THE MUSLIM RULE
}

| Received December 4th 2015 | Accepted January 9th 2016 | Available online June 30th 2016 |

| DOI http://dx. doi. org/10.18860/jia.v4i1.3167 |

Sumaiya Ahmed

The Department of Islamic Studies,

Aligarh Muslim University (AMU),

Aligarh, India

sumi.ahmad21@gmail.com

\begin{abstract}
The mosque constitutes one of the most highly developed forms of religious architecture. With the rapid expansion of the Muslim community through conquests as well as missionary activities, it became necessary to set aside an enclosed area in cities or large towns for the purpose of established communal worship. Mosque architecture in the Muslim period exposes clearly its sacred identity, even it is continuously remarked, but in secular architecture, the ideas are not spiritually motivated in a cosmic sense. Definitely a structural idea and use of materials as well as its functional and aesthetic use play a role in determining what is expressed by it. The development of understanding of functional and aesthetic use of materials and technique with effective manner is depending on assimilated technologies. Integrated process of standard materials, skilled labor, innovative idea and socioeconomic as well as geographical factors may regard to constructing any magnificent architecture. The present study is an attempt to analyse and develop the structure, structural decoration and use of materials and design of the mosques during the Muslim period in Bengal.
\end{abstract}

KEYWORDS:

Architecture; Community; Mosque; Muslim; Muslim Period

\section{INTRODUCTION}

When the Muslims established their power permanently in this sub-continent, they already possessed a highly developed architecture of their own. There are certain elements which have become especially associated with this architecture. Fundamentally speaking, they are arch and dome, minarets and mihrabs. These elements are common throughout the Muslim world. But, besides these there are a number of local elements that get the upper hand in different regions and localities. These differences make for local styles. They bear the character of the land upon which they flourish. The Muslim architecture that developed in Bengal had an individuality of its own, and it bears a definite stamp of this deltaic land. In contrast to the green and gold mosaics of Jerusalem and Damascus, or the superb coloring of Persian title work, or the wonderful fantasies of Spanish design, Bengal offer her marvelous art designs in terracotta that take their inspiration from the jungle scenes of this land [1].

The cataclysmic waves of Muslim invasion in the twelfth and the thirteenth centuries reached Bengal with a thrust that left an indelible imprint in the land of the Buddhists and the Hindus, the original inhabitants of the region. In the land of stupas and temples Mosque was certainly a noble and characteristic variation in the field of building art. It is true that whatever the Muslims went, they erected mosques to meet the fundamental religious requirements, that is, congregational prayer five times a day. But in boldness of design and grandeur of conception the splendid mosques built during the early phase of Muslim rule in Bengal reflect the genius of Muslim architects and their adjustability to local architectural influence. It is obvious that when the Muslims came as invaders to India and finally Bengal they brought with them masons and decorators who have long been trained in the art of building in the style prevalent in their regions [2].

\section{BACKGROUND}

The mosque constitutes one of the most highly developed forms of religious architecture. With the rapid expansion of the Muslim community through conquests as well as missionary activities, it became necessary to set aside an enclosed area in cities or large towns for the purpose of established communal worship. Mosque architecture in medieval time exposes clearly its sacred identity, even it is continuously remarked, but in secular architecture, the ideas are not spiritually motivated in a cosmic sense. Definitely a structural idea and use of materials as well as its functional and aesthetic use play a role in determining what is expressed by it. The development of understanding of functional and aesthetic use of materials and technique with effective manner is 
depending on assimilated technologies. Integrated process of standard materials, skilled labor, innovative idea and socioeconomic as well as geographical factors may regard to constructing any magnificent architecture. The evolution of Indo-Muslim architecture in the twelfth and the thirteenth centuries may be described as a synthetic process: the impact of Islam in India was overwhelming, but this does not negatively influenced the Indian architectural skill on the formation of a truly distinctive style of Islamic architecture in India. The Muslims brought with them their own architectural skill and traditions. They, however, found a completely different environment in India, to which their traditions of architecture had to be accommodated. The architectural traditions in India during the medieval period where vertical and horizontal, which was mastered to formulate structural ideas by both the Hindu and the Muslims. The Mughal (The Mughal rule was a branch of the Timurid dynasty. From the early sixteenth century to the early eighteenth they built and ruled the Mughal Empire on the Indian subcontinent, mainly corresponding to the modern countries of Bangladesh, India and Pakistan. Their power rapidly dwindled during the eighteenth century and the last of the emperors was deposed in 1857 , with the establishment of the British Raj) followed the homogeneous style which followed in the Sultan-i -Mosque. The buildings of the Mughal period show the powerful influence of the Delhi (capital of India at present) style. In the context of the structure, Mughal mosques of Dhaka (capital of Bangladesh at present) are the existing example of gradual transformation of the foreign elements to the taste of local concept and tradition. Abroad architectural ideas imported into India, particularly religious one, dominated by the mosques, from Persia and central Arabia. The impact of foreign construction and design technique, successive use of materials and adaptability of ideas with domestic existing theme is the main focal point of this article. Here Indian and traditional Muslim architecture exclusively interior and exterior structure of the mosque will be studied. It is hoped that this study will trigger more research on medieval mosques of Bengal in the future[3].

\section{MUSLIM CAME IN BENGAL}

Low-lying delta area in the north-west corner of the Indian subcontinent. The character of Bengal is largely determined by the Ganges and Brahmaputra rivers which divide into innumerable branches before entering the sea. Although the area is currently divided between the two modern states of India and Bangladesh it retains a certain homogeneity based on its language (Bengali) and culture [4].

The victory of Muhammad Bakht- yār Khaljī at Nadiya in A.D. 1204 marks a new epoch in the history and culture of Bengal. The history henceforth turns on to record the onward march of the Muslim arms from West Bengal to South and East until the entire Gangeto -Brahmaputra delta was brought under their complete sway. This region, which henceforth bore the name of Sultanate-i-Bangala or Subah-i-Bangala, was in the past surcharged with Hindu-Buddhist spirit, but now it felt the impact of Islam. The early Arab contact with the Bengal coast has left no recognizable remains on the surface, except a faint memory in 'Buddermokan' associated with the Muslims as recorded by Harvey. The influence of Islam in the cultural field was gradual but definite, and as a result of the clash of its ideals with those of the earlier forces, we find the people of this region coming within the fold of Islam in such a great number that the whole atmosphere of this humid land today breathes in the spirit of the desert-born Islam. The Muslim had come to Bengal with their developed civilization of Islam as their heritage and they meant to settle down in the country in order to establish a new home for themselves. The caries of this civilization, who mostly Turks, had themselves were uprooted from their homeland in Central Asia and they came here as squatters to make a bid for a new career in their life. They introduced the new martial vigor and the great heritage of the Islamic civilization that they brought in their train, but how these new elements fitted into the ever-recurring humid climate of Bengal, is a long history [5].

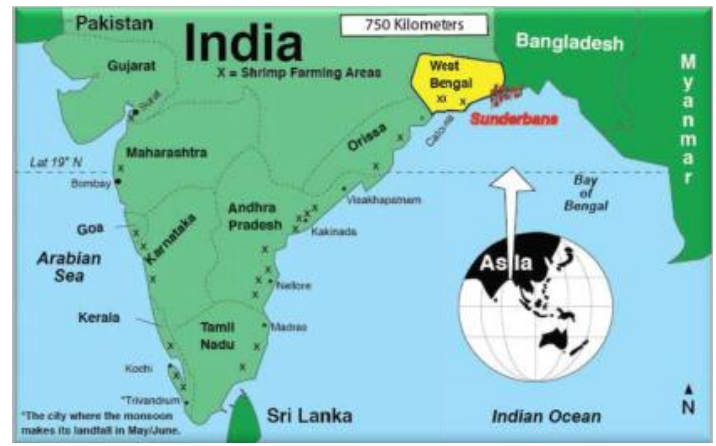

Figure 1. Map of India (Asia continent) indicate the position of the Bengal, after 1947, partition of India Bengal divided into two parts: west Bengal (India) and Bangladesh (Independent country)[6]

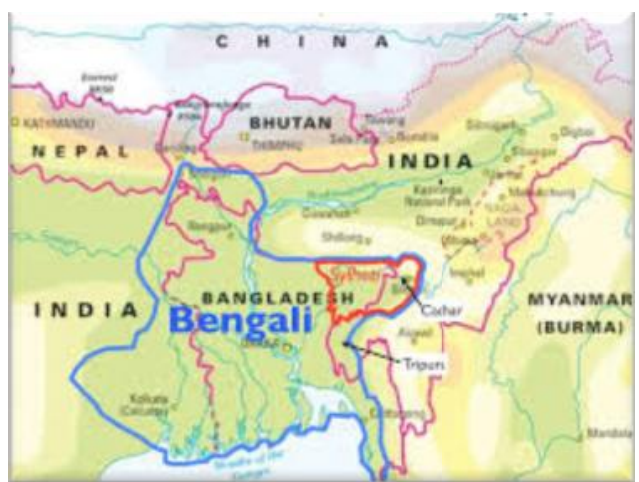

Figure 2. Position of Bengal (Indian Subcontinent)[7]

An attempt is made here to understand this phenomenon in the field of architecture, which expresses but one aspect of human life, but it is the most important in so far as it is a social product 
demanding the coordinate effort of peoples divergent in beliefs, customs and manners, often at war with one another. The Human desire for durability and beauty makes them sink their enemies in order to produce a building which would serve their purpose. It is on these buildings that the human attempt at a common endeavor is writ large and we get at the back of human mind that goaded them to build such monuments. It is through them that we shall try to see how in the changing styles of architecture the conquering Muslims advanced to adjust their mind to the environment of Bengal [8].

\section{HISTORICAL OVERVIEW OFTHE MOSQUES}

The Masjid is a microcosm that engulfs all the Muslims within the macrocosm of Muslim brotherhood and a symbol of fraternal unity and solidarity throughout the Muslim world. Masjid par excellence is not merely a veritable exhibition of the monumental art done in a most sacramental way, but also an emblem of religious fervor and sacerdotal obligations of Muslim Ummah. It is, therefore, quite evident that Masjid formed the genesis of Muslim architecture from the day the Holy Prophet Muhammad $\square$ (PBUH) laid the foundation of the first Mosque of Islam at Madinah and his favorite follower Hadrat Belal chanted the first azan from the roof of that Mosque [9]. Since then Mua'zzins have been calling the Faithful to Mosques for congregational prayers five times a day from the tall tapering minarets throughout the Muslim world. As a distinctive type of Muslim religious building art, Mosque is a veritable symbol of Islam. Derived from sajada,the Masjid or Mosque is obviously a place of prostration and divine worship with utmost humility and religious fervor. Unlike Stonehenge, Greek alters, Roman basilica, Fire-Temple, Jewish Tabernacle, Christian Church, Buddhist Temple, and Hindu Shrine, Mosque was not the product of a highly organized liturgy and priesthood. Mosque never expounds mythology or mysticism, but a moving and unaffected piety, a soul -searching spirit, enabling the worshippers to realize the transcendental qualities of an omnipotent, Omniscient Allah. As Islam condemns all self-centered individualistic types of prayer, the Mosque has pre-eminently acquired breadth and spaciousness hitherto unknown in dark and mysterious cells of many non-Muslim shrines [9].

\section{MEANING OF THE MOSQUE}

A Muslim place of prayer. The English word 'Mosque' derives, via the French Mosque the old French Mousquaie, the old Italian Moschea and Moscheta and the old Spanish Mezquita, from the Arabic word Masjid, meaning a place of prostration before Allah. The word masjid (and its plural Masājid) appears twenty seven times in the Qur'ann, fifteen times in the phrase al masjid al harām, the Holy Mosque, where it pre-symbol refers to the sanctuary surrounding the $K a^{\prime} b a$ in Mecca. The word Masjid, is used once in the phrase Al -Masjid al Aqsā 'the furthest mosque. In
Muhammad $\square \quad$ (PBUH) lifetime this probably referred to a place of prayer in heaven, although later commentators universally understood this phrase to refer generally to the sanctuary of Jerusalem and especially to the Mosque erected at the south end of the Temple Mount. Other uses of the word Masjid in the Qur'ān indicate that it could be applied to any place where Allah was worshipped, whether in Islamic or pre-Islamic times. The Qur'ān gives absolutely no indication of what, if any, from a Masjid should take and perfectly valid worship may be performed after ablution virtually anywhere using only the most minimal marking on the ground or a mat or rug when Muslims gather in groups for communal worship, they line up in rows facing the Qibla or direction of prayer and repeat a series of prayer leader, perform a series prostrations.Starting from these modest begins, over the centuries Muslims have built praying places of great power and beauty that count among the finest examples of world architecture. This article will discuss the history and development of structures and their constituent elements as they evolved over the centuries [10]. If architecture is an expression of human will in brick and mortar to create something sublime something to express his distinctive genius on the canvass of nature which is ever ready to merge him within her lap -it is necessary that the architectural forms are studied and styles appreciated against the demand of local conditions. The motives of man are understood only when he is appreciated in the particular surroundings in which he is placed. The Buildings are not end -products in a vacuum. They are created to meet certain conditions of life, and it is in the fulfillment of these conditions that the highest achievement of man is realized [11].

\section{METHODS}

This study deals with the Mosques Architecture of Bengal built between the independent sultanate of Bengal and the end of Afghan rule, when Akbar (Mughal Ruler) conquered Bengal and it became a suba or mosques form a homogeneous group of Muslim monuments in this area, in sharp contrast to those of the Mughal period that followed: while the sultanate architecture of Bengal differs markedly from the Dehli, the buildings of Mughal period show the powerful influence of Dehli style.

\section{MUSLIM RULE IN BENGAL}

Bengal, the land of gold and green, came under Muslim rule in 1204 when Muhammad Bakht- yār Khalji, a general of Qutb ud Din Aibak, took over Nadiya, the capital city of the Sen Dynasty in lower Bengal and establish himself at Gaur or Lakhnauti (Gour), also known as Lakhnauti, is a ruined city on the IndiaBangladesh border, most of the former citadel is located in present-day the Malda district of West Bengal, India, while a smaller part is located in Nawabganj District of Bangladesh) as the governor of the newly established Turkish Empire. The Muslim 
rule so established was strengthened and extended by subsequent rule either under the nominal subordinates to the Dehli Sultanate(1206-1526 A.D.) or independent chieftains. We hear names of several generals and governors who rebelled against the Central authority and declared independence. Among these the so called llyas Shahis stand out prominently, whose progenitor, Shams u'd din llyâs, proclaimed independent in 1345.Among his successors were Sikandar Shah and A 'zam Shah Mahmud (1442-59). The latter is known for his building enterprises, for example, he rebuilt the capital of Gaur and constructed a mosque at Sonargaon. Shah Husain (1493-1518) or Sayyid u's- Sâdât 'Alâ u'd Din Abu'l Muzaffar ShahHusain Sultan, to name him in full was, however, the greatest ruler of Bengal after Ilyâs.After him the dynasty suffered decline because family feuds and conspiracies were engineered among the various centres for power.The situation deteriorated to the extent that Jalâl Khan and his son Sher Khan got prominence until the establishment of the Mughal Empire in 1526 when Humâyun got temporary possession of Gaur.However, in 1539, he was ousted by Sher Shah, who became the independent ruler of Bengal [12].

It has been claimed that the Muslim rulers and following them, their nobles and elite erected several monumental buildings, both religious as well as secular, throughout the empire. The twin cities of Gaur and Pandua (Pandua also spelt Pandooah is a census town in Hooghly district in the Indian state of West Bengal) often served as the capital in the sultanate period, while Vikramapur (Vikramapur (Munshiganj) the political and cultural centre of ancient Bengal survives only in the name of an area in the Munshiganj district of Bangladesh. The remains of the city of Vikramapur, the capital of the ancient kingdoms of south-eastern Bengal, are lost and its location can only be guessed on the basis of available data) Sonargaon (Sonargaon also transcribed as Sunārgāon, meaning (ity of Gold) was a historic administrative, commercial and maritime center in Bengal. Situated in the center of the Ganges delta, it was the seat of the medieval Muslim rulers and governors of eastern Bengal), Dhaka and Many others had Monumental edifices like mosques, madrasas, tombs, caravanserais, fortifications, bridges and causeways, built into them [13].

Bengal, a riparian country with immense alluvial soil deposits, is a brick building region as stone and marble quarries are totally absent, though a few examples of stone structures and stray stone elements are observable. The Mughal mosques of Dhaka are all built of brick. But the carved brick ornamentation of the pre-Mughal period was replaced by the flat surface decoration of plastering. The cornice tended to be more horizontal than curvilinear as observable in preMughal structures. The paneling on walls with niches and rectangular frames now adorned the walls of the Mughal mosques. The arch no longer retained twocentered, pointed, variety, but recourse to fourcentered type, occasionally feature of imperial Mughal architecture as observed in the Tomb of Humayun at
Dehli and the Taj Mahal at Agra(famous city of India), and it was totally absent in Bengal [14].

One fascinating aspect of natural harmony can be found in the traditional architecture of the Bengali mosque, which is seen as fitting within a natural setting rather than forcing itself on its surroundings. The monumental mosque architecture of the fabulous capitals. Such as Gaur, Pandua, Dhaka, Murshidabad (is a city in Murshidabad district of West Bengal state in India) and Rajmahal (is a city and a notified area in Sahibganj district in the Indian state of Jharkhand) - sends out a different, as this architecture represents royal patronage and majestic taste. However, the overall nature of Islamic art and architecture in Bengali is not imposing rather, it belongs to the natural background in its basic character. In the vast rural mosques are used for daily prayers that draw their architectural vocabularies from local traditions on the natural settings. Typical examples are the Bengali village mosques that have thatched roofs and mud-walls, somewhat similar to the original Masjid al- Nabaei (The Prophet's mosque) one of the earliest mosques in Madinah. Often natural ponds are attached to these Bengali Mosques. These serve as a place of Wudu (ablution). These simpler places of prayer also contributed to the rural population easily accepting Islam. The rural architecture of the Muslim villagers reminds us that the focus of Islamic architecture is not to be solely on buildings; rather, it should be about people their environment and ecology [15].

\section{SOME FEATURES OF MOSQUE ARCHITECTURE}

The Bengali style of architecture broadly falls into two chronological phases, the pre-Mughal and the Mughal [11]. The main distinguishing features of the buildings of the two periods are as follows [16]:

1. Most of the pre-Mughal buildings, except the very few early ones, have the curvature of the parapet and the cornice, but this was not adopted in the buildings of the Mughal period in which the parapet and cornice are horizontal and straight.

2. The arch in the pre-Mughal buildings is twocentered and pointed, emanating from heavy piers or pillars; whereas in the Mughal buildings it is four-centered

3. The dome in the buildings of the pre-Mughal period is usually semi-circular and without any shoulder drum so that it lacks height and grandeur. It also rests on pillars which divide the interior of the buildings (mostly mosque) into aisles and bays. Consequently the number of domes equals the number of aisles into bays, or rather the number of front -doors inthe sidedoor. The domes in the Mughal buildings, on the other hand, stand on the shoulders and hence they attain a height and beauty, they also rest not on pillars but on transverse arches. Consequently the mosques of the Mughal period are not of the multi-domed type of the previous 
period, but are mostly either three-domed or single-domed.

4. Finally the walls of the pre-Mughal buildings are not plastered, but are decorated generals with terracotta designs. The Mughal buildings, on the other hand, are plastered and the decorations are also generally made of plaster work.

\section{PRE -MUGHAL PERIOD}

The predominant form of Islamic architecture in Bengal is the mosque. In pre-Mughal Bengal the Mosque was virtually the only form of Islamic building, although after the sixteenth century a wide variety of Islamic building types such as the caravanserai and madrassa were introduced characteristic features of Bengali mosques of all periods are multiple mihrabs, engaged corner towers and curved cornices. Although multiple mihrabs sometimes occur in North India, Bengal is the only place where they are a constant feature in mosques. The number of mihrabs is determined by the number of entrances in the east wall. Engaged corner towers are a constant feature of Bengali architecture and may derive from pre-Islamic temples. Curved cornices are probably derived from the curved roofs of bamboo huts, it is possible that they may have a practical function for draining water away from the base of the domes. During the preMughal sultanate three types mosque were built, rectangular, square nine -domed and square single domed. During the pre-Mughal sultanate three types of mosques were built, rectangular, square ninedomed and square single domed.A Mosque built on a rectangular plan are divided into aisles and bays, according to the number of domes on the roof. At the east end of each aisle is a doorway and at the west end a mihrab. There are also openings on the south and north sides of the mosque corresponding to the number of bays. The nine -domed mosques are similar to those found elsewhere in the Islamic world, but they differ in having three mihrabs at the west-end. The most popular form of mosque in pre-Mughal Bengal was the single -domed chamber [17]. So, here discussed some great Muslim dynasty during the preMughal period in Bengal.

\section{MAMLUK PERIOD (1227-1281)}

The early period of the Muslim rule in Bengal, which is associated with the sultanate of Lakhnauti, was the time of the provincial governors who generally bore the title of Malik. They ruled more or less in subordination to Dehli authority and existed entirely on their untiring zeal for war against the neighbouring rivals Hindu rajas. They had to assert their own right in the contending ideals of the time. The seed of the Muslim rule that they had sown, hard to grow, lest it lost its strength and got overpowered by the mushroom growth of the petty Hindu Kingdoms. A new idealism was to be born out of the clash of interests, in which the right of the new invaders was to find due recognition. The necessities of their life were to be fulfilled at the expense of others. The way of their living should find scope in the tin buildings. It is but natural that this ideal is reflected in the contemporary architecture. In their general pattern the buildings proclaim the Muslim source of inspiration an indebtedness to the common tradition which by then had already developed in Delhi. Thus, the buildings are an epitome of the then architectural achievements of the Bengalis placed at the service of the Muslim conquerors. This early phase of construction from the beginning of the Muslim rule of the foundation of the Independent Sultanate in Bengal (from 1204-1338) is studied under the Mamluk style [11].

This is the formative period of the Bengali architecture in which the beginnings of new taste are dimly visualized. Owing to later restoration many of the original features have undergone changes, but enough remains to show the typical brick style and the brick and stone style of Bengal. The multi -domed mosques are quite popular, but we do not find here the corner towers, not the curved roof. On the other hand the front row of arches spring directly from huge piers -an appearance which strikes ill to the eye. But the terracotta ornamentation finds its due place at the mihrab [11].

\section{EARLY ILYAS SHAHI PERIOD(1352-1414)}

The break-up the Muslim empire in about the middle of the fourteenth century A.D. led to the establishment of regional kingdoms, but the building programme of the Tughlaqs (The Tughlaq dynasty (Persian: ), also referred to as Tughluq or Tughluk dynasty, was a Muslim dynasty of Turkic origin which ruled over the Delhi sultanate in medieval India. Its reign started in 1320 in Delhi when Ghazi Malik assumed the throne under the title of Ghiyath al-Din Tughluq. The dynasty ended in 1413)continued unabated during the reign of Firoz Shah Tughlaq (A.D.1351-1388. It was after invasion of Timur in A.D.1398 that the capital city of Delhi lay exhausted and denuded of its treasures. The builders naturally dispersed into the newly-risen kingdoms, and it is only in the fifteenth century A.D. that the Tughlaq influence is mainly left in the provincial architecture. Bengal started the independent career with the revolt of the Fakhruddin Mubarak Shah at Sonargaon, in A.D. 1338, but it was left to the Shamsuddin Ilyas shah, a new arrival probably from the Panjab, to establish the rule of his own dynasty in this deltaic land, with capital at Hazrat Pandua (The word Hazrat is used in order to distinguish this town from Chhota Pandua in Hooghly district in West Bengal, India in present day), the Firozabad of the Muslim historians. Ilyas Shah united the three regions- Lakhnauti, Satgaon and Sonargaon under his authority and bore the significant title of Shah-i- Bangala. Henceforward the nomenclature changed from the Sultanate of Lakhnauti to that of Bangala. The llyas Shahi buildings make a bold attempt to evolve a grand style befitting the dignity of the new state [11]. 
So, this period is known mainly from the great Adina Mosque at Hazrat Pandua, though other smaller buildings are known from the other places. The Adina is a new experiment in Bengal as far as its general plan and design is concerned. It called forth the best of masons, stone workers and materials that were then available. It is a bold creation unique in its kind, and though displaying many details of the Bengali elements, it can hardly be regarded as a next stage in the development of the Bengali style [11].

\section{REPRESENT THE EKLAKHI STYLE BETWEEN THE EARLY AND LATTER ILYAS SHAHI PERIOD}

The independent kingdom in Bengal created a rivalry between the newcomers, who had accompanied Ilyas Shah and founded the Muslim Sultanate of Bengal and local supporters of Ilyas, who has dreamt of a regeneration of their cherished aims and ideals. The political opportunities favoured the rise of a Hindu chief Raja Ganesh (1415-33 A.D.), who manipulated the circumstances to win over the throne for his own converted son Jadu-Jalaluddin(d. 1431)and thus establish the rule of his dynasty. Ganesha infused a strong local current into the spirit of the time, but he could not change the course in favour of the Hindu rule. He met with a strong opposition in the personality of Hazrat Nur Qutb 'Alam, the great saint of Hazrat Pandua, who stood fast to the claim of Islam and ultimately won over the son of the Hindu Raja. Jalaluddin became a disciple of the saint and made a happy comprise between the two contending parties. The result was the dawn of a new age, in which Muslims and Hindus alike co-operated to evolve a common cultural heritage in Bengal. Now where else is the spirt of the time better reflected than in the buildings erected at this time. The social emotions that were stirred in this period could alone conceive of a building of the type of Eklakhi Style at Hazrat Pandua [11].

The Eklakhi represents the true brick style of Bengal, with massive walls, octagonal corner towers, curved parapet, and terracotta ornamentation, the wall surface variegated with offsets and recesses, and above all the numerous lines of mouldings. The glazed tiles are for the first time used in this building [11].

\section{LATTER ILYAS SHAHI PERIOD(1435-1487)}

Nasiruddin Mahmud I ushered in " the most flourishing period of Lakhnauti, its most flourishing period of Lakhnauti, its Augustan age, in which period were constructed the best and the finest remains now existing." With his enthronement the House of Raja Ganesha came to an end, and the old dynasty of llyas Shah was restored amidst the plaudits of the people. The restoration not only revived the feelings of loyalty to the dynasty, but also inspired the rulers to the fulfillment of those aims and ideals that had just taken shape during the reign of the local converted dynasty. There was no reaction in this period of the llyas Shahis. All their benevolent works indicate a culmination of those currents of social life that were set rolling with the foundation of the independent Sultanate in Bengal [11].

This period is a fully developed architectural style of Bengal. The defects of the Eklakhi and the Adina are here removed. This is the period when the Bengali architecture reached its classical phase. The adjustment of the buildings of the classical phase. The adjustment of the buildings to the surroundings, the well-balanced plan and adequate ornamentation -all produced an effect that is really charming [11].

\section{HUSAIN SHAHI PERIOD (1494-1538)}

The Latter Ilyas Shahi dynasties were upstarts, among whom Saifuddin Firoz was a man of genius and personality. His death in A.D. 1490 has again been opportunity to the self-seekers to make a bold bid for the throne. The fortunate ones succeeded to occupy it one another, but their ill-famous deeds drove the people to rebellion. The people won over the support of Sayyid Husain, the shrewd wazir of the last ruler Shamsuddin Muzaffar (Sidi Badr Diwana). When his fate was decided, Sayyid Husain was proclaimed king in A.D. 1493 amid people's rejoicing. He founded the Husain Shahi dynasty, under whose rule Bengal expended in her political boundary and prospered in trade and commerce [11].

Then, the Husain Shahi rulers introduced an era of peace and prosperity, the building activity in Bengal received a further stimulus. The large number of mosques was built all over the place. At this time we find both brick style and brick and stone style followed side by side. The decorations reached greater height, even to the extent profusely, and some of the domes, as the two Golden Mosques at Gaur, were gilded [11]

MUGHAL PERIOD (SUBAH-I-BANGALAH PROVINCE OF MUGHAL EMPIRE 1556-1717)

Bengal is studded with mosques, particularly of the Mughal period. Any foreign visitor would be pleased at the sight of the skyline presented by Bengal for innumerable mosques ranging over a thousand in small localities as well as important civic but also testify to the deep religious favor of the Muslims. Architecturally speaking, these splendid buildings are unique examples of provincial version of the imperial Mughal architecture, though certainly they were not mere blind copies. Under Mughal dispensation building style underwent drastic change compared to the preMughal brick and terracotta architecture. Mughal mosques had to suit themselves to new forms and techniques. A glimpse of the Muslim architecture of Bengal can obtain from some of the existing Mosques phases [14].

\section{AGE OF AKBAR}

Until 1575 Bengal was under the control of various Afghans houses. Then Akbar's troops brought into the Mughal Empire. Subsequently, several revolts against Akbar's authority were staged by renegade nobles of the Mughal camp. Ironically, during this 
chaotic period, a Mughal style of architecture had a marked regional character. It was founded on a well established Islamic style in Bengal illustrated by several monuments constructed on the eve of Mughal authority there. Among these are the double aisle sixdomed Mosque of Kusumba built in 1558-59 and the square plan single domed tomb of Pir Bahram in Burdwan dated 1562-63. The former is stone, while the latter is brick -constructed, and both like most preMughal architecture of Islamic Bengal has a prominent curved cornice. Their plan and elevation even the ornamental brick -reflect forms that were at the time several centuries old. From this foundation, the Mughal style of Bengal evolves [18].

\section{AGE OF SHAH JAHAN}

The lasting impact of Mughal architecture was felt later in Bengal. Little had been built here in Jahangir's reign. Even at the beginning of Shah Jahan's reign, the pan-Indian Mughal aesthetic had not yet penetrated Bengal. For in the first year of Shah Jahan's reign 1628-29, the Khondakar Tola Mosque at sherpur was completed. A buildings clearly inspired by the nearby Kherua mosque of 1582 indicating a reliance on local building traditions. This single aisled brick constructed mosque was provided by Sadr Jahan. A local religious official. Shortly after this. However, building styles began to reflect those at Mughal centers throughout India. Several monuments of this period remain in Dhaka, an important mercantile center and military outpost. Ancldgah of 1640-41 and a serial known as the Bara Katra, dated between 16431646, were provided by Abd al-Qasim, the administration there. Little remains today of his once splendid series. Its multi - storied entrance gate, however. Still stands and its similar to Aczam Khan's serai entrance in Ahmadabad built less than a decade earlier. The cldgah was modeled closely on saif Khan's Patna cldgah of 1628. The mosque inside Dhaka's Lalbagh fort dated 1649, is typical of Shah Jahan period architecture in Bengal. For example, the faceted recessed arches of the central entrance are also seen on the nearby Bara Katra and the contemporary mosques of Rajmahal. Its cusped arched and rows of recessed niches give this single - aisle three bayed mosque a more refined quality than those in contemporary Rajmahal. In spite of its fluted domes an eighteenth century restoration, it remains the best example of the fully mature Mughal Mosque type of this period in Bengal [19]. The Mughals introduced a number of important architectural features in Bengal. These came gradually, meanwhile the earlier style and features persisted for sometimes longer. A notable example of this continued local style is the Qutb Shähi Mosque at Hadrat Pandua, built in 1582 by Makhdūm Shaikh, a descendant of Sheikh Nūr Qutb al-'Ālam, in whose honour the mosque is so called. It is built of bricks with roughly cut stone facing on the walls, and follows the usual oblong plan, measuring externally 82 feet 6 inches by 37 feet 8 inches and having corner towers crowed with cupolas. The interior is divided into 2 aisles and five bays by a row of four stone pillars that originally supported 10 domes, now all fallen. Corresponding with the aisles and bass respectively, there are two arched doors each on the northern and the southern side, and five arched doors in the eastern wall in line with five mihrabs in the western wall. The parapet and cornier are curved. The façade is plain except for the bands of mouldings on the walls and the offers a towers. Here discussed some important mosques during the Muslim period: Some Grand Mosques in Bengal during the Muslim period (Pre Mughal- Mughal Period): Adina Mosque (1373 A.D.) In Fourteenth century:

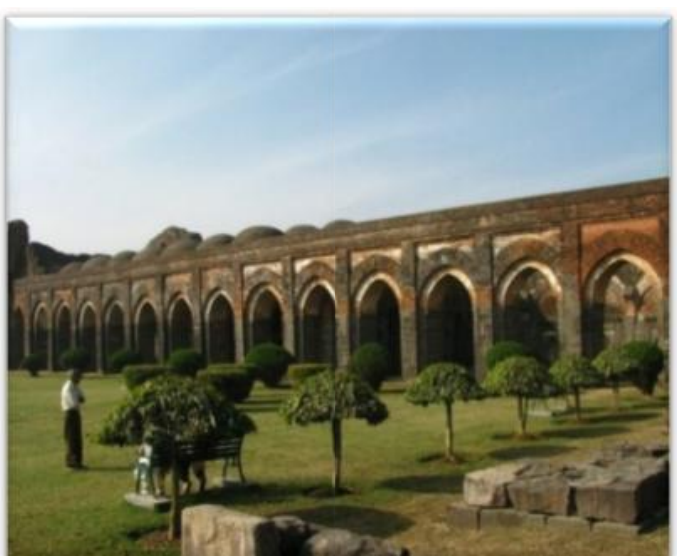

Figure-3. Adina Mosque [20]

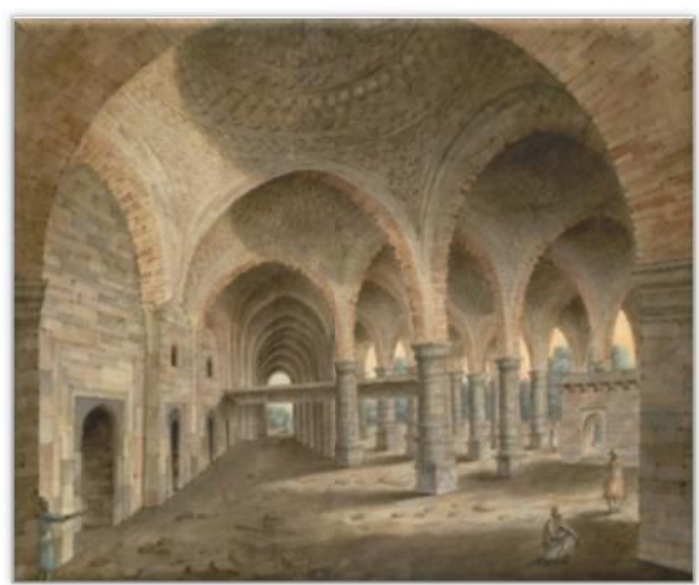

Figure 4. Adina Mosque Inside [21]

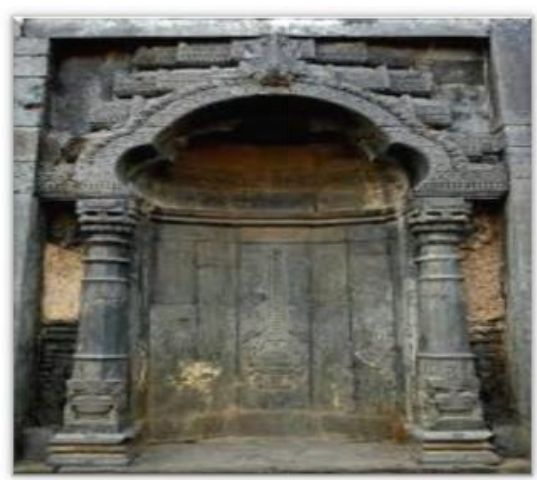

Figure 5. Mihrab (prayer niche) at Adina Mosque [22] 
The Adina Mosque at Pandua near Gaur in Bengal exemplifies a more distinctive local style, combing features from both east and west. One of the largest mosques in India $(155 \times 87 \mathrm{~m}$.), it consists of a series of hypostyle halls arranged around a courtyard. The courtyard façade is a screen of 88 arches supported on piers and surmounted by a parapet. In the centre of the Prayer hall, a massive iwan like barrel vaulted hall leads from the court to the mihrab and minbar. Now roofless and shattered. The vault was framed by a high screen, undoubtedly modeled on the Iranian Pishtaq. Stone spolia from temples were used for the lower parts of the building, but brick was used above the imposts for the arches and the 370 brick domes. Three bays to the north of the mihrab is a raised platform that was originally screened and surmounted by a parapet. In the center of the prayer hall, a massive iwan-like barrel -vaulted hall leads from the court to the mihrab and minbar. Now roofless and shattered, the vault were farmed by a high screen, undoubtedly modeled on the Iranian. Stone spolia from temples were used for the lower parts of the building, but brick was used above the imposts for the arches and the 370 brick domes. Three bays to the north of the mihrab is a raised platform that was originally screened and surmounted by 18 domes higher than those over the other bays of the prayer-halls. This type of platform is found in several large mosques of the sultanate period and probably served as an elevated Maqsura. Although the size and plan of the Adina Mosque are atypical of other Bengali mosques, which are much more modest in scale, its multiple mihrabs are typical of mosques in the region. Such as the mosque of Zafar khan Ghazi in Tribeni (1298) which was five. The grandiose quality of the Adina Mosque and the similarities to buildings in Islamic lands further west can be explained by the ambitions of the patron, who in the foundation inscription, called himself "the most perfect of the sultans of Arabia and Persia" [23]. But now it is in ruins followed by the earthquakes in 19th and 2oth centuries [24].

\section{SATH-GUMBAD MOSQUE IN BAGERHAT (BANGLADESH)IN MID-15TH CENTURY (1442- 1459)}

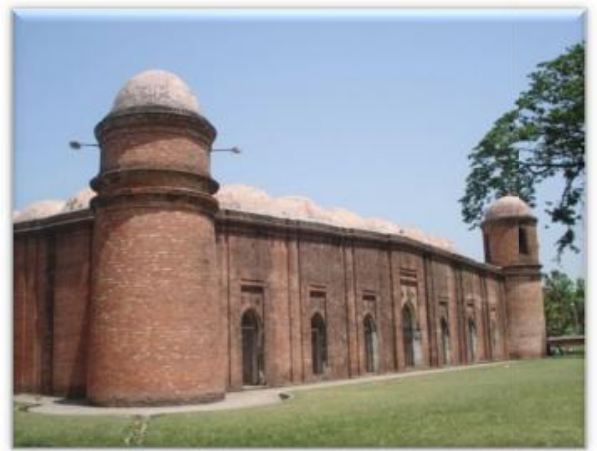

Figure 6. Sath-Gumbad Mosque [25]

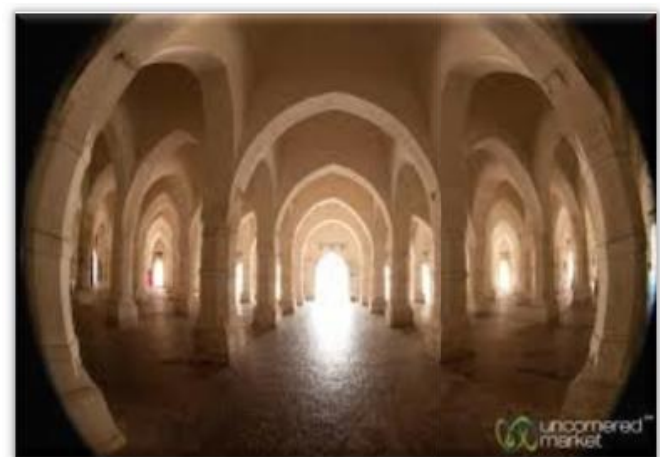

Figure 7. Sath-Gumbad Mosque Inside [26]

The red brick mosque of sixty domes built by a local ruler Khan-I- Jahān Ali, is a massive structure of considerable dimension. The Liwân measures $160 \mathrm{ft}$. from north to south and $108 \mathrm{ft}$. from east to west. The façade on the east has eleven slightly recessed, twocentred arched openings or doorways, while each corner has been strengthened with batter towers surmounted with dome lets. The central opening is slightly higher than the others. Above, a cornice runs all through the length of the front-end, while the central arch has a triangular pediment. Internally, the chamber is divided into eleven aisles from north to south, and seven from east to west, while the western wall has been provided the mihrabs in the shape of two-centred, engrailed arched recesses. The domed roof is raised on slender octagonal pillars of stone. Seven central bays have pyramidal domes, but the others are surmounted by hemispherical domes. The square shaped aisles have been divided at the top into octagons by means of pendentives erected with corbelled brick work. The mihrabs are conceived of a gate -like framework having decorative floral patterns in low relief [27]. It is now a pilgrimage site where people pay homage to the man who dedicated his lifetime to build the city and its monuments. The Pir Ali Tomb (of Pir Ali, a close associate of Khan Jahan) is an annex building of this mausoleum and is of identical layout. A mosque called the Dargha Mosque is attached to the mausoleum [28].

\section{MOSQUE OF BINAT BIBI (1454 A.D.)}

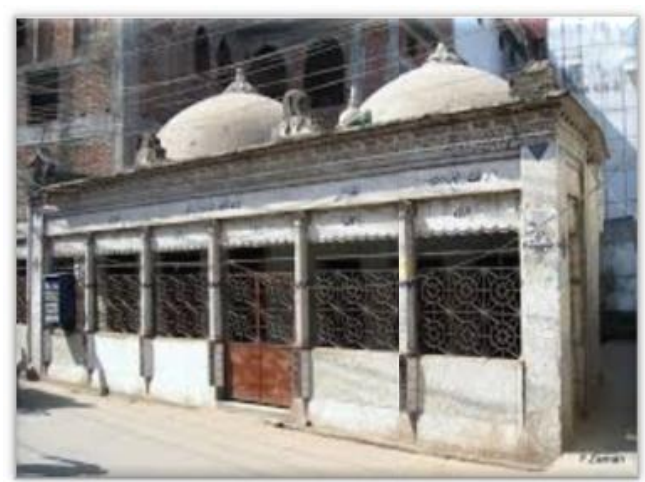

Figure 8. Mosque of Binat Bibi [29] 


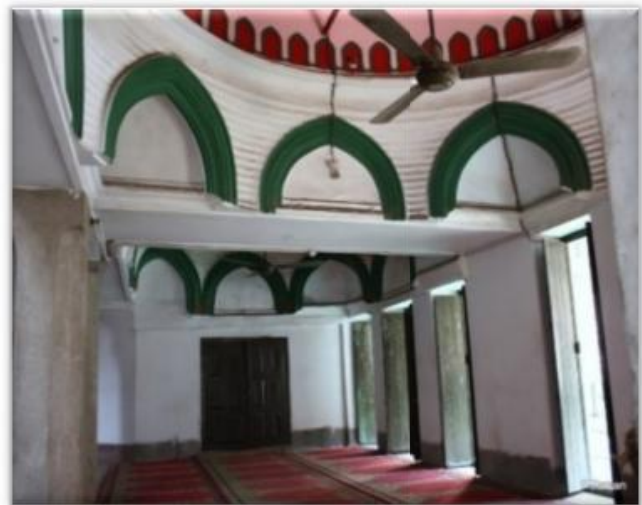

Figure 9. Binat Bibi Inside [29]

That the modern city of Dhaka, was a flourishing center of trade and commerce as well as religious and cultural activities before the arrival of the Mughals is evident from a number of old and dilapidated monuments. In pre -Mughal Dhaka, a thickly populated Muslim Community, humming with various vocations emerged in the eastern part of the city called Narandia or the present Narinda, by the side of the old Dhulai canal, which is now filled up to make a modern road. In all probability a prosperous township came into being in this area during the reign of Sultan llyas Shah in the fifteenth century as demonstrated by the erection of a beautiful Mosque which was evidently the centre of Muslim community life. From the architectural standpoint, it was originally a neat square single-domed type of buildings as observable in Gaud. Though completely orientated in recent times, its preMughal features are quite perceptible. The Mosque measures 12 feet square internally and is entered by three arched doors from the east, the north and the south. The square chamber is crowned by a single hemispherical dome. It was originally - un- plastered as most pre Mughal monuments are. The most distinguishing features of the Mosque are curved cornier and battlements which are still visible in the Qibla side. It is the earliest serving Muslim religious building in Dhaka, which has undergone alterations by the addition of a domed prayer room to the south and new verandah on the east and the south [14]. At the present time, Part of the mosque is being demolished as part of a renovation plan which includes building a 70 -foot $(21 \mathrm{~m})$ high minaret, and the extension of the current building from three stories to seven [30].

\section{BABA ADAM SHAHID MOSQUE, RAMPAL(1483 A.D)}

Named after the celebrated Saint of the area, Bâbâ Âdam. Shahid, the Mosque was built by Malik Kâfur during a time of Fateh Shah, the last llyas Shahi ruler. The mosque, rather the Liwân, is built on an oblong piece of land measuring $434 \mathrm{ft}$. Long and $36 \mathrm{ft}$. Broad, with usual octagonal corner turrets. The façade on the east has three, two-centered arched openings within a slightly projecting frame work. Above, the cornice is convex in shape. The prayer chamber is surmounted with three hemispherical domes, while in the west wall are created three mihrabs is the shape of engrailed, two centred archedniches richly decorated [31]. There is a grave of a saint of Muslim named "Baba Adam" just beside the mosque. It's heard from the people that, during the ruling period of Ballal Sen, "Baba Adam" came to that place to spread the religion Islam. But "Baba Adam" was killed by the order of "Ballal Sen", and he was buried here later on [32].
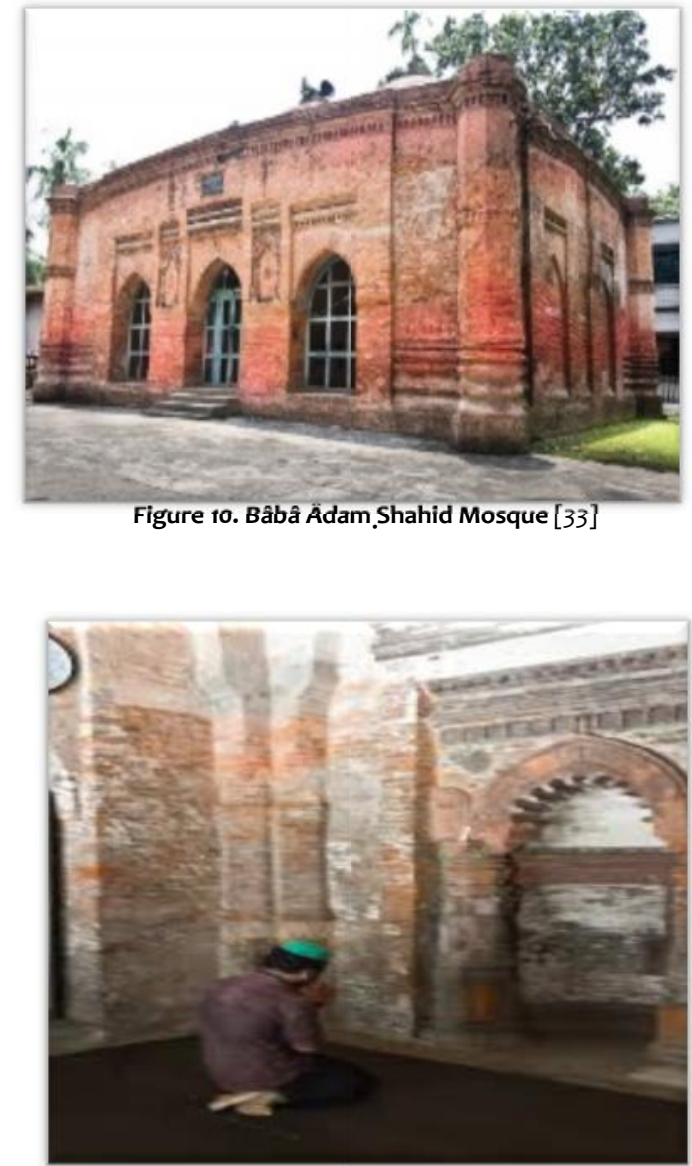

Figure 11. Bâbâ Âdam.Shahid Mosque Inside [33]

CHHOTA SONA MOSQUE, FIRUZPUR, GAUR(1493 AND 1526)

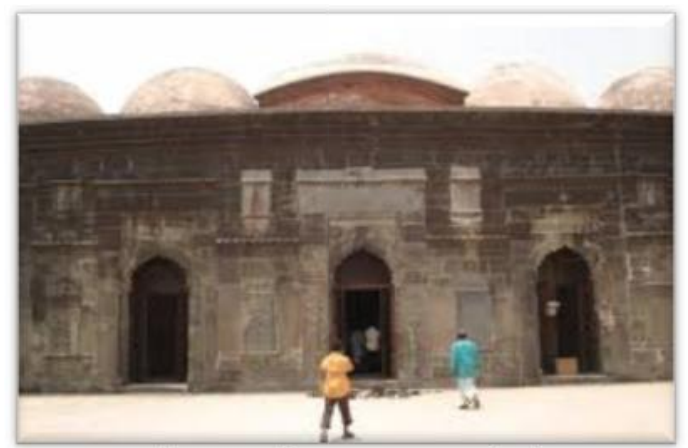

Figure 12. Chhota Sona Mosque [34] 


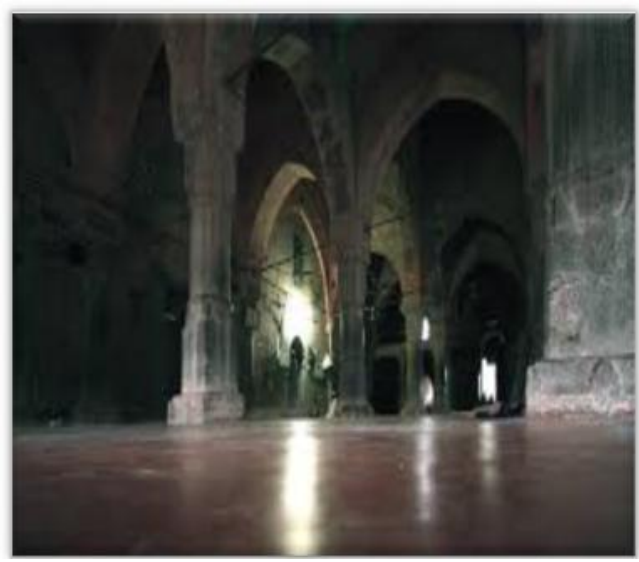

Figure 13. Chhota Sona Mosque Inside [35]

One of the most celebrated mosques in Bengal, the chhota Sona mosque (the little gold mosque) was, according to the epigraph fixed over the façade of the central compartment, built by Wali Muhammad, son of Ali, during the rule of 'Ala ud Din Husain Shah (14931519). Unfortunately, the portion of the inscribed stone carrying the date has been chipped off. The date, therefore, cannot be discerned, the other bigger version, the great gold mosque, was built later by the same patron at Ram Kali, West Bengal. It had a gilded surface on the dome, also sparingly ornamented with green blue, white, yellow, and oranges tiles. As usual, the mosque is marked with the Liwan which is an oblong measuring $82 \mathrm{ft}$. From south to north and $52 \mathrm{ft}$. from east to west. It is strengthened with corner turrets provided on each corner. The eastern facade with stone revetment has rich floral as well as epigraphical carving. Here, the entire space has been divided into several oblong panels to have this floral carving , invariably, the oblong panel ha sa full blown lotus carved very boldly, while the central doorframe has been given more rich treatment, the east side has five openings in the shape of multi-foiled, two centred, engrailed, arched door frames are arranged a series of friezes and panels of different sizes and designs, mainly string courses and dentils arranged right up to the parapet, which itself consists of a series of decorative mouldings that also run consecutively on the corner turrets and on other sides of the building. The chamber is crowned with three chauchâla vaults in the centre and four hemispherical domes flanking them. on the north and south sides were two doorways each, while on the west exteriors is a framed projection, marking the back of the mihrab with two turrets flanking the projection, and going in the shape of cupolas, the prayer chamber measures $741 \mathrm{ft}$. and 9 in. from south to north and $40 \mathrm{ft} .6 \mathrm{in}$. ft. $40 \mathrm{~m}$ east to west internally and has been divided into three aisles and five bays by stone pillars, the central compartment is bigger than those flanking it, It is roofed by three vaulted domes. The entire surface both interior as well as exterior is decorated, though not very effectively, with floral designs in low relief [27]. The glamour of the Chhoto Sona Masjid is not there as it was originally, particularly because of the stripping of the decorative mihrabs and the mosque courtyard, but the remains are nevertheless one of the most attractive monuments of Guar-Lakhnaut [36].

\section{CHURIHATTA MOSQUE(1649 A.D.)}

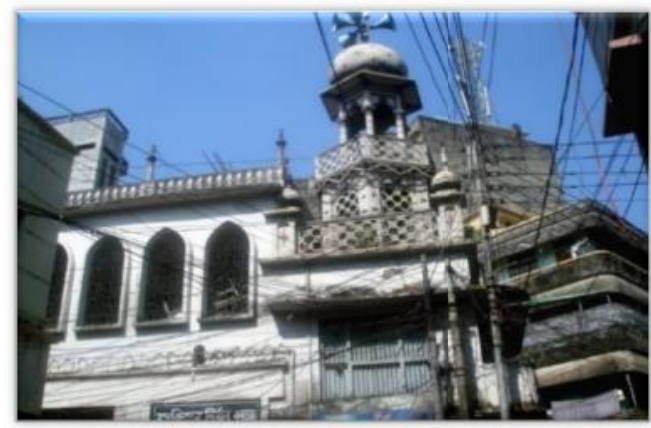

Figure 14.The Churihatta Mosque [37]

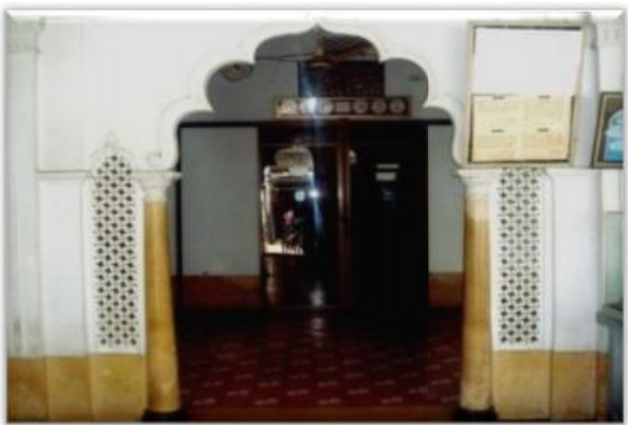

Figure 15. Churihatta Mosque Inside [37]

The Churihatta quarter of the city near the chauk is situated Churihatta mosque, which is characterized by bungalow type of roof, so much spoken of in the Baharistan-i-Ghabi. The mosque was built by a Mughal officer, Muhammad Beg in 1649, when Prince Shah Shuja was the viceroy of Bengal. The mosque's rectangular in plan with towers at the four corners. The eastern side has three doorways, each of which opens through two successive arches. The façade is marked with numerous square and rectangular panels and the cornice, which is straight, is faced with blind merlons. The interior hall is covered with an intersecting vaulted roof, the line of intersections is curved and so is the central ridge. But this vaulted roof is a development from the north Indian pyramidal type. It has no long drawn eves as found in the Bengali type. The mosque is now renovated [27].

\section{MOSQUE OF KARTALAB KHAN (MURSHID KULL) A.D. 1700-} 04

Kartalab Khan was appointed Diwan or Revenue administrator of Bengal by Emperor Aurangzeb during the vice-royalty of Azimus-Shah. His original name was Muhammad Hadi but he earned the title of kartalab khan from Emperor Aurangzeb for his efficiency in revenue Administration. After coming to Bengal, he 
erected a mosque at Dacca, known after his name. The Mosque is undoubtedly one of the most impressive Mughal structures of Dacca, having been built on a high platform called tahkana. There are vaulted rooms underneath, which are now being used as shops. Unlike the tree-domed mosques of Khan Muhammad Mirdha, it is roofed over by five domes resting on octagonal drums. The most curious architectural feature of the Mosque is the do-chala or two segmented hut-shaped structure, adjoining the mosque on the worthy, which is used as their residence of the Iman. There was a stepped well or built about the same time in the courtyard of the mosque [38].

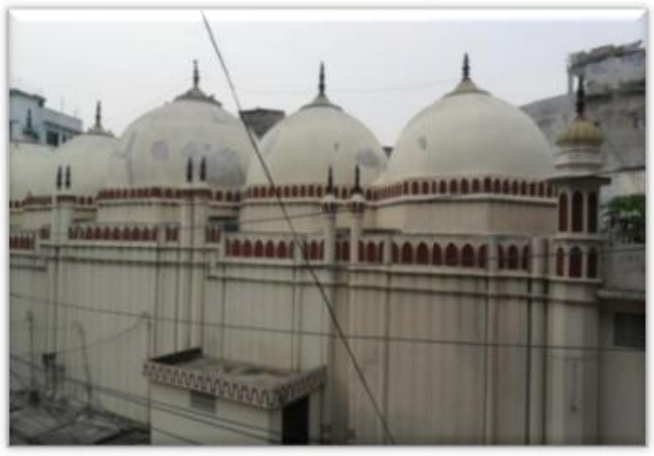

Figure 16. Mosque of Kartalab Khan [39]

\section{KATRA MOSQUE (1723-1724)}

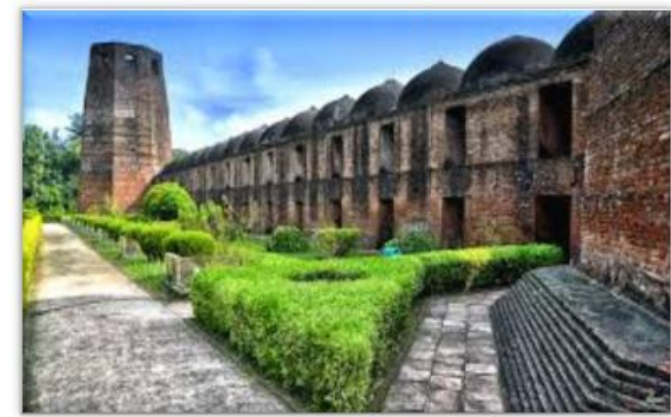

Figure 17. Katra Mosque [33]

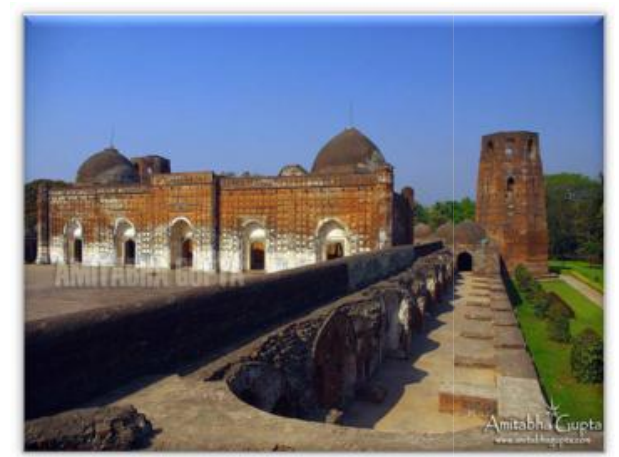

Figure 18. Elevated View of Katra Mosque alias Katra Masjid [40]

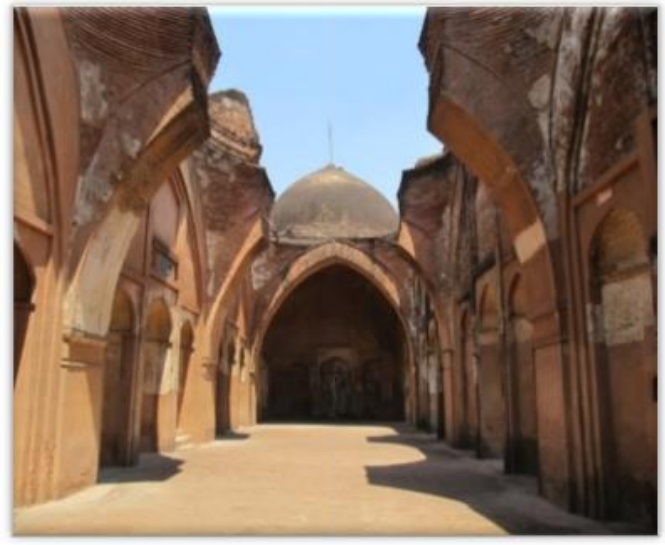

Figure 19. Katra Mosque Inside [29]

The most significant architectural project in the new headquarters was a Jami Mosque, dated 1724-25, and called the Katra Mosque today. While the mosque's plan and an overall elevation adhere to established Mughal standards other aspects of the mosque link it and its patron, Murshid Quli Khan to long-standing traditions of Bengal. The numerous niches of the Jami mosque's façade and the weighty quality suggested by the proportionally small entrance arches do not recall contemporary Mughal construction, but are reminiscent of ornamentation of pre-Mughal architecture in Bengal. This break with the Mughal ornamental style corresponds with the autonomy of its patron, despite his nominal allegiance to the center. There is one other parallel to that suggests a link between Bengal. Bengal practice and the new leader Murshid Quli khan. Like Sikandar Shah, the most not the ruler of fourteenth century Bengal, who was buried under the entrance to his Adina Mosque in Pandua, Murshid Quli Khanarranged to be buried under his own Mosque's entrance. In essence, Murshid Quli Khan increasingly free of Mughal authority, expressed a regional rather than panMughal affiliation by associating himself with the independent rulers of pre-Mughal Bengal. Surrounding the Mosque on all four sides is domed cloistered chambers that served as a splendid madrasa staffed with 2,000 reciters of the Qu'rān. Murshid Quli Khan's zeal in propagating the faith is well known from historical chronicles, not altogether surprising since he was a convert to Islam. The construction of this madrasa cum-mosque, larger than any Mughal mosque built in Bengal, endows the city, hither to holding little religious significance, with a dominant sacred importance - possibly an attempt to rival the traditional centers of piety in Bengal, Gaur and Pandua [41]. At present it is maintained and protected by the Archaeological Survey of India and the Government of West Bengal [42].

Hence, these grand Mosques provide us golden architectural design ideas which we can incorporate with the modern design and construction technique and glorify our past heritage [43]. 


\section{CONCLUDING REMARKS}

Architecture is the mother of all arts, as it encompasses the science and art of designing and building, painting and sculpture and the decorative arts, In fact the art of buildings expressed the deep seated aspirations of a nation and also the most positive expression of the elective character of its culture. In the words of William Hicking Prescott, "the surest test of the civilization of a people at least, as sure as any afforded by mechanical art is to be found in their architecture, which presents. So noble a field for the display of the grand and the beautiful and which at the same time, is so, intimately connected with the essential comforts of life". The Architectural heritage of a country is moulded not only by the geographical and strati- graphical conditions and the shifting tendencies of political and social history, but also the inherent religious impact, spontaneous artistic tradition, profound extraneous influence and aesthetic consciousness of the builders. Therefore, any comprehensive study of a country's architectural heritage is pre-conditioned by its physical setting, historical background, social, cultural backdrop and the last but not the least aesthetic and utilitarian purposes. This is true in the case of Bengal. Bengal has long been considered as a 'crucible of culture and for being situated in the south -eastern tip of the subcontinent it attracted a host of people the Arabs, the Persians, the Turks and the Afghans. They left behind distinctive traits of their history and culture which ultimately led to the formation of a dynamic and magnificent heritage in the form of mosques [44]

The Bengali Muslims developed a distinctly regional style of architecture that had popular appeal. By infusing their own methods and teachings of construction new life was given to forms that already existed and were well known in Bengal and in neighboring areas. Throughout the Islamic period this tradition continued, assimilating the changes brought about by Muslim rulers in their construction. The Muslims took an existing form, adapted it to their needs, enriched it, and shared it with the culture whence it came [45].

\section{REFERENCES}

[1] A. H. Dani, Muslim Architecture in Bengal, Dacca (Bangladesh). Pakistan: Asiatic Society of Pakistan, 1961.

[2] D. S. M. Hasan, Dacca the City Of Mosques, Dacca (Bangladesh). bangladesh: Islamic Foundation Bangladesh, 1981.

[3] A. T. M. Shamsuzzoha and H. Islam, "Structure, Decoration and Materials: Mughal Mosques of Medieval Dhaka," J. Bangladesh Assoc. Young Res., vol. 1, no. 1, pp. 93-107, 2011.

[4] A. Petersen, Dictionary of Islamic Architecture. London and New York: Routledge, 1996.
[5] A. H. Dani, Muslim Architecture in Bengal, Dacca. Pakistan: Asiatic Society of Pakistan, 1961.

[6] "No Title." [Online]. Available: www.shrimpnews.com. [Accessed: 05-Nov2015].

[7] “Geocurrents," 2015. [Online]. Available: http://www.geocurrents.info/. [Accessed: 27Nov-2015].

[8] Ahmad Hasan Dani, Muslim Architecture in Bengal, Dacca. Pakistan: Asiatic Society of Pakistan, 1961.

[9] Dacca the City Of Mosques. op. cit., p. i.

[10] J. D. M. (ed), "Encyclopedia Of The Quran," Encycl. Quran, vol. vol-3, pp. 426-428., 2003.

[11] Muslim Architecture in Bengal. op. cit, P.9.

[12] A. N. Khan, Islamic Architecture in South Asia: Pakistan-India-Bangladesh. New York: Oxford University press, 2003.

[13] A. N. Khan, Islamic Architecture in South Asia: Pakistan -India -Bangladesh,. New York: Oxford University press, 2003.

[14] Dacca The City Of Mosques. Cit, Op.

[15] S. E. H. (ed) Ishrat Alam, A Varied Facets Of History: Essay In Honor Of Aniruddha Ray. Dehli: Primus Books, 2011.

[16] Muhammad Mohar Ali, History Of The Muslims Of Bengal. Riyadh: Imam Muhammad Ibn Sa'ūd Islamic University, 1985.

[17] Dictionary of Islamic Architecture. op. cit.

[18] A. Ansari, A complete Book on Mughal Architecture History. New Dehli: Cyber Tech Publications, 2010.

[19] A complete Book on Mughal Architecture History. New Dehli: Cyber Tech Publications, 2010.

[20] "No Title." [Online]. Available: http://www.westbengaltourism.gov.in/. [Accessed: 27-Nov-2015].

[21] “Columbia University," 2015. [Online]. Available: http://www.columbia.edu/. [Accessed: 27-Nov-2015].

[22] "Himal," 2015. [Online]. Available: http://old.himalmag.com/. [Accessed: 27-Nov2015]. 
[23] J. M. B. and S. S. Blair(ed), The Grave Encyclopedia Of Islamic Art And Architecture. New York: Oxford University Press, 2009.

[24] "Famous Mosques in India." [Online]. Available: http://www.indiamapped.com/mosques-inindia/. [Accessed: 05-Feb-2016].

[25] "Wikipedia." [Online]. Available: en.wikipedia.org. [Accessed: 27-Nov-2015].

[26] "World for Travel." [Online]. Available: http://www.worldfortravel.com/. [Accessed: 27-Nov-2015].

[27] Architecture In South Asia. op. cit.

[28] Wikipedia, "Mosque City of Bagerhat," 2016. [Online]. Available: https://en.wikipedia.org/wiki/Mosque_City_of _Bagerhat. [Accessed: 05-Feb-2016].

[29] “Panoramio." [Online]. Available: http://www.panoramio.com/. [Accessed: 27Nov-2015].

[30] Wikipedia, "Binat Bibi Mosque," 2016. [Online]. Available: https://en.wikipedia.org/wiki/Binat_Bibi_Mosq ue. [Accessed: 05-Feb-2016].

[31] Islamic Architecture In South Asia. op. cit.

[32] “Munshiganj: Baba Adam Mosque," Lonely Traveler, 2010. [Online]. Available: http://icwow.blogspot.co.id/2010/06/munshiga nj-baba-adam-mosque.html. [Accessed: 05Feb-2016].

[33] “No Title." [Online]. Available: www.flickr.com. [Accessed: 27-Nov-2015].

[34] “Picturestats." [Online]. Available: https://picturestats.wordpress.com/. [Accessed: 27-Nov-2015].
[35] "The History Hub." [Online]. Available: http://www.thehistoryhub.com/. [Accessed: 27-Nov-2015].

[36] Wikipedia, "Choto Sona Mosque," 2016. [Online]. Available: https://en.wikipedia.org/wiki/Choto_Sona_Mo sque. [Accessed: 05-Feb-2015].

[37] “No Title." [Online]. Available: commons.wikimedia.org. [Accessed: 27-Nov2015].

[38] Dacca the City of Mosques. op. cit.

[39] "Offroad to Bangladesh." [Online]. Available: http://offroadbangladesh.com/. [Accessed: 27Nov-2015].

[40] "Flickriver." [Online]. Available: http://www.flickriver.com/. [Accessed: 27-Nov2015].

[41] C. T. Catherine B. Asher, India before Europe. UK: Cambridge University Press, 2006.

[42] Wikipedia, “Katra Masjid," 2016. [Online]. Available:

https://en.wikipedia.org/wiki/Katra_Masjid. [Accessed: 05-Feb-2015].

[43] S. Hasan and T. Corresponding, "The Contextual Issues in the Islamic Architecture of Bengal Mosques," vol. 3, no. 1, pp. 41-48, 2013.

[44] S. M. Hasan, Glimpses of Muslim Art and Architecture. Dacca (Bangladesh): Islamic Foundation, 1983.

[45] P. Hasan, Sultanate Mosques and Continuity in Bengal Architecture. . 